\title{
Oceanographers fear greater federal involvement
}

THE increasing activities of missionoriented federal agencies in oceanographic research threatens to undermine a creative tension between government, industry and universities, according to a report published by a panel of the National Academy of Sciences.

The report also warns that a desire for "useful" research, coupled with possible research restrictions in foreign territorial waters, is shifting the emphasis from oceanography as a science searching for principles and understanding to oceanography as a tool with which to accomplish practical goals.

The report was prepared by an ad hoc committee established by the Academy's National Research Council to study the geological and geophysical research needs and problems of the continental margins. The chairman was Dr Alber W Bally of the Shell Oil Company.

Stating that a substantial increase in funding for research on domestic continental margins could produce considerable benefits in terms of both scientific knowledge and information about mineral resources, the committee says that it is disturbed by recent trends in the distribution of responsibilities between govern- ment, universities and industry.

"Overall federal money for oceanographic research has increased substantially in recent years, but most new funds have gone to mission-oriented government agencies. Funding for basic oceanographic research done by scientists in academic institutions has barely kept up with inflation", the report says.

It suggests that government should concentrate primarily on research related to its function of governing and regulating the use of public resources - and that a considerable amount of future research effort should be delegated to universities.

The report also expresses concern about the possible impact of restrictions emerging from the Law of the Sea Conference, now under negotiation by the United Nations, under which scientists would require permission to conduct research within 200 miles of a country's coastline.

Given these restrictions, as well as the importance of scientific knowledge as a basis for resource exploitation, the report argues that "the time is ripe" to concentrate more research on domestic continental margins.

"Science - and particularly oceano- graphy - is international. However we believe that an effort with increased emphasis on national concerns is needed. We are recommending an increase in the momentum of solid-earth science research in our own back yard."

Commenting on the likely restrictions on international research, the report points out the irony that in recent years, pressure to demonstrate the social relevance of scientific research has caused university scientists to submit proposals containing rhetoric extolling the potential social impact of their work.

"Because of the emphasis placed on justifying research as having significance for resource evaluation, great strain may be placed on the credibility of the researcher if he proposes to do similar work on foreign margins, claiming it to be 'pure' scientific research"' it says.

The report suggests that a strong academic domestic research programme on US continental margins might help to convince foreign sceptics that US academic institutions "are not implicitly interested in prospecting, that their interest is to contribute to the understanding of principles related to resources and to the environment."

\section{WHO looks at $b$ \\ THE potential of certain bacteria, notably} strains of Bacillus thuringensis, for the control of insect vectors of tropical diseases is being actively examined by the World Health Organisation, in collaboration with a number of laboratories on both sides of the Atlantic. For many years, strains of $B$. thuringensis have been marketed by a number of pesticide manufacturers in commercial formulation for use against the larvae of various lepidopterous pests, but it is only recently that the potential of the serotype $\mathrm{H} .14$ (also known as $B$. thuringensis israeliensis) has been fully appreciated. This strain is now known to be extremely lethal for the larvae of certain Diptera, including mosquitoes of the genera Aedes and Culex which are vectors of malaria and filariasis respectively (although somewhat less so, apparently, against Anopheles). Now WHO sees the possibility of using it to control the blackfly, Simulium damnosum, the vector of onchocerciasis (river blindness).

On the commercial side, development is already going ahead, notably on the part of the Franco-Belgian firm Bellon-Biochem. They are working in close collaboration with the Pasteur Institute, where Dr Huguette de Barjac leads a team in this field. The first results from serotype H.14 formulations were so encouraging that Biochem decided to go straight to field testing, thus leap-frogging the lengthy procedure in a way that WHO itself could never do. The results against blackfly larvae in the Ivory Coast have so far shown

\section{bacteria for vector control}

very high toxicity rates, with, a report states, "nearly total short-term innocuity against the associated non-target fauna"'.

The nature of the new material, however, has raised problems in its largescale application that have yet to be resolved. The larvicidal action, it appears, is due to crystalline toxic compounds present on the outer coating of the bacterial spore. These operate in fact as a chemical insecticide. Unfortunately they have a high specific density, tending to sink to the bottom in water, and one problem is therefore to find a formulation that will keep the toxic materials afloat long enough for them to reach the target larvae downstream of the point of application. This in turn raises difficulties in attaining the concentration necessary to achieve the experimentally predicted results.

It is therefore necessary to put the maximum amount of crystal toxin into the primary powder used as a basis for the actual pesticide, and then to formulate the latter in such a way as to give the desired residual effect under normal field operating conditions. From the commercial point of veiw, the development of such a formulation could probably enable the manufacturer to patent his material, a matter of great importance in the highly competitive pesticide industry. Moreover, any such formulation must also pass the stringent requirements of most governments with regard to safety against mammals. This aspect is also being examined in a number of laboratories.
However, with government support in several countries - notably France, the USSR and Switzerland - it looks as though the new materials may reach a stage in the quite near future where mass field trials can be undertaken under WHO auspices.

The current resurgence of malaria, with increased resistance to normal insecticides as well as to therapeutics, and the pressure to find alternatives to such materials as DDT, will certainly encourage research in this field. Quite apart from its enormous potential for use against the vectors of malaria and other mosquito-borne disease, the new material could provide a valuable stand-by alternative to the pesticide Abate. The huge onchocerciasis control programme in the Volta Basin in West Africa at present depends entirely on this one pesticide for blackfly control.

Peter Collins.

\section{France seeks bioengineers}

France this year needs $30-40$ biotechnologists familiar with such things as the purification of proteins, fermentation, and cell cultures. Next year there will be a need for $60-80$ and the year after 120-160, according to a report reviewed last week by le Monde. The report is part of a massive work 'Sciences de la vie et société' prepared by Francois Jacob and available for consultation in Paris. 